\title{
At-Turats
}

Jurnal Pemikiran Pendidikan Islam

\section{PENGEMBANGAN MATERI AJAR MENULIS PUISI MELALUI MEDIA AUDIO-VISUAL PADA SISWA KELAS II SD/MI DI MIN I BANTUL YOGYAKARTA}

\author{
Rahmaniatul Fithriyah, S.Pd, \\ rahmafitri88.rf@gmail.com ${ }^{1}$ \\ UIN Sunan Kalijaga
}

\begin{abstract}
This research aims to develop teaching materials to write poetry through audiovisual media in class II, SD / MI. To produce a product in the form of stage writing poetry in a simple child through audio-visual media in teaching material grade II SD / MI by the Research and Development of simplified, includes three main stages, namely 1) the preliminary study; 2) formulation and product development; 3) validation and product dissemination. Results of this research is the stage of writing poetry through audio-visual media that can be done in three stages: knowing, thinking, feeling. Know is the initial stage of introducing the theme of the poem to be written specified in two phases, namely: pre-foundation phase and foundation plantings. Imagining is the stage after the children turn imagination shown in visual media specified in three phases, namely: Phase reseftivitas, reactivity and productivity. Soaking is the stage where the state according to the image and theme supported by appropriate audio poetry themes detailed in two phases, namely: the implementation phase and exploration.
\end{abstract}

Keywords: Development, Writing Poetry Children and Audio-Visual Media

\section{PENDAHULUAN}

Seperti yang diungkapkan oleh H.G. Tarigan, bahwa menulis merupakan kegiatan menurunkan atau melukiskan lambang-lambang grafis yang menggambarkan suatu bahasa yang dipahami oleh seseorang sehingga orang lain dapat membaca lambang-lambang grafis tersebut jika memahami bahasa dan gambaran grafis itu. ${ }^{2}$ Dengan kata lain menjelaskan bahwa menulis merupakan sarana komunikasi secara tidak langsung. Komunikasi tersebut

\footnotetext{
${ }^{1}$ Mahasiswa S2 Pendidikan Guru Madrasah Ibtidaiyah Universitas Islam Negeri Sunan Kalijaga Yogyakarta.

${ }^{2}$ H.G. Tarigan, Menulis Sebagai Suatu Keterampilan Berbahasa, (Bandung: Angkasa, 1994), hlm.21.
} 


\section{At-Turats}

Jurnal Pemikiran Pendidikan Islam

journal homepage: http://jurnaliainpontianak.or.id/index.php/atturats

di tuangkan atau disalurkan melalui media lain untuk menyampaikan maksud dari tulisan tersebut kepada orang yang membaca. Pendapat yang sama juga dikemukan oleh Syafi'ie yang menyatakan bahwa menulis adalah menuangkan gagasan, pendapat, perasaan, keinginan, dan kemauan, serta informasi ke dalam tulisan dan kemudian "mengirimkannya" kepada orang lain. ${ }^{3}$ Dapat disimpulkan bahwa kedua pendapat tersebut mendefinisikan menulis sebagai cara berkumunikasi dari satu orang kepada orang lainnya untuk menyampaikan pesan melalui media tertentu. Cara berkomunikasi dengan menulis merupakan suatu keterampilan yang dapat ditingkatkan dengan terus menerus dilatih. Hal ini mendukung pendapat Tarigan bahwa keterampilan menulis tidak akan datang secara otomatis melainkan harus melalui latihan dan praktik yang banyak dan teratur. ${ }^{4}$

\footnotetext{
${ }^{3}$ Syafi'ie, Retorika Dalam Menulis, (Jakarta: Departemen Pendidikan dan Kebudayaan, 1988), hlm.45.

4 H.G. Tarigan, Menulis Sebagai Suatu Keterampilan Berbahasa,... hlm.3.
}

Sedangkan puisi menurut Herman J. Waluyo adalah karya sastra dengan bahasa yang dipadatkan, dipersingkat dan diberi irama dengan bunyi yang padu \& pemilihan kata-kata kias atau imajinatif. ${ }^{5}$ Pengertian di atas dapat kita simpulankan bahwa puisi merupakan karya sastra yang berisi tentang kalimat-kalimat yang penuh dengan kiasan dan berbunyi dengan irama yang padu. Lain halnya dengan Sayuti yang menyatakan bahwa puisi merupakan hasil kreatifitas manusia yang diwujudkan lewat susunan kata yang mempunyai makna. ${ }^{6}$ Dari kedua pengertian puisi diatas dapat kita simpulkan bahwa puisi merupakan karya sastra yang lahir dari hasil imajinasi manusia yang disalurkan lewat kalimat yang berisi kata-kata yang padat dan mempunyai kiasan yang berirama.

Dalam menulis puisi bagi anak SD/MI yang berada di kelas II juga bukan merupakan hal yang mudah untuk itu dapat dibantu dengan

5 Herman J. Waluyo, Teori dan Apresiasi Puisi, (Jakarta: Penerbit Erlangga, 2002), hlm.1.

${ }^{6}$ Suminto A. Sayuti, Berkenalan dengan Puisi, (Yogyakarta: Gama Media), 2008, hlm. 12. 


\section{At-Turats}

Jurnal Pemikiran Pendidikan Islam

journal homepage: http://jurnaliainpontianak.or.id/index.php/atturats

hadirnya media-media pembelajaran yang diciptakan oleh guru. Tujuan guru menghadirkan media-media pembelajaran adalah untuk mempermudah siswa dalam mengerti penjelasan serta nantinya juga dapat dengan mudah untuk mempraktikkan. Sebagaimana sesuai dengan pengertian media pembelajaran itu sendiri yang merupakan alat yang dapat membantu proses belajar mengajar dan berfungsi untuk memperjelas makna pesan yang disampaikan sehingga dapat mencapai tujuan pembelajaran dengan lebih baik dan sempurna. ${ }^{7}$ Terdapat berbagai macam bentuk media pembelajaran secara garis besar, yaitu: (1) Media Berbasis Visual; (2) Media Berbasis Audio; (3) Media Berbasis Audio-Visual. Pada materi ajar menulis puisi dapat siswa dapat dibantu dengan adanya media pembelajaran berbasis audio-visual. Dibandingkan jika guru dan siswa hanya mengimajinasikan di dalam fikiran, akan lebih mudah dan gampang apabila sesuatu yang menjadi sumber inspirasi hadir dalam

7 Cecep Kustandi dan Bambang Sujipto, Media Pembelajaran Manual dan bentuk dapat di lihat oleh mata dan juga dapat di dengar secara langsung. Penelitian yang relevan dengan penelitian pengembangan materi ajar menulis puisi melalui media audio-visual pada siswa kelas II SD/MI di MIN I Bantul Yogyakarta, yaitu : penelitian dari Lina Turofingah, Suhartono, dan Tri Saptuti Susiani yang berjudul "Peningkatan Keterampilan Menulis Puisi Melalui Penggunaan Media Audiovisual Pada Siswa Kelas V SDN Keleng 01”. Dari penelitian tersebut dapat disimpulkan berdasarkan hasil pelaksanaan tindakan dan pembahasan, dapat disimpulkan bahwa prosedur penggunaan media audiovisual sebagai berikut; (1) persiapan; (2) pelaksanaan; (3) tindak lanjut. Selain itu penggunaan media audiovisual dapat meningkatkan keterampilan menulis puisi siswa kelas V SDN Keleng 01 Tahun Ajaran 2012/2013. Penggunaan media audiovisual dalam pembelajaran menulis puisi mengalami kendala, di antaranya: kurangnya kejelasan gambar video

Digital, (Bogor: Ghalia Indonesia, 2013), hlm.8. 


\section{At-Turats}

Jurnal Pemikiran Pendidikan Islam

journal homepage: http://jurnaliainpontianak.or.id/index.php/atturats

dan kesulitan siswa pada aspek diksi.

Berdasarkan kendala yang muncul, solusi yang diberikan untuk mengatasi kendala tersebut yaitu: guru sebaiknya memperhatikan dan memeriksa media audiovisual sebelum media tersebut digunakan, dan menyarankan siswa agar banyak membaca contoh puisi, sehingga siswa mempunyai banyak perbendaharaan kata.

Penelitian yang selanjutnya adalah penelitian dari Maria Sepriyenni Saragih, Asmayani Salimi, dan Sugiyono yang berjudul "Penggunaan Media Audio Visual Untuk Meningkatkan Hasil Belajar Menyimak Dalam Pembelajaran Bahasa Indonesia". Dari penelitian ini dapat disimpulkan bahwa meningkatkan hasil belajar siswa menggunakan media audiovisual pada mata pelajaran Bahasa Indonesia kelas III Sekolah Dasar Mazmur 21 Pontianak Selatan dapat disimpulkan:

1) Kemampuan guru dalam melaksanakan pembelajaran Bahasa Indonesia khususnya aspek menyimak dengan menggunakan media audio visual pada siswa kelas III Sekolah Dasar Mazmur 21
Pontianak Selatan adalah cukup baik karena dengan guru menggunakan media audiovisual sebagai media pembelajaran terbukti dapat meningkatkan hasil belajar siswa pada mata pelajaran Bahasa Indonesia khususnya aspek menyimak. 2) Peningkatan hasil belajar menyimak menggunakan media audio visual dalam pembelajaran Bahasa Indonesia pada siswa kelas III Sekolah Dasar Mazmur 21 Pontianak Selatan sudah dapat dilakukan oleh guru dengan sangat baik terbukti dengan melihat peningkatan dari persentase rata-rata yaitu meningkatnya persentase hasil belajar dari siklus I sebesar 66,00 meningkat naik pada siklus ke II menjadi 77,70.

Penelitian ini bertujuan untuk mengetahui hal-hal sebagai berikut, yaitu: (1) landasan penggunaan media dalam pendidikan; pengembangan materi ajar menulis puisi di SD/MI melalui media audiovisual; dan (3) pelaksanaan materi ajar menulis puisi pada siswa kelas II SD/MI di MIN I Bantul Yogyakarta. Penelitian ini menggunakan metode penelitian pengembangan (Research and Development). Menurut Borg dan 


\section{At-Turats}

Jurnal Pemikiran Pendidikan Islam

journal homepage: http://jurnaliainpontianak.or.id/index.php/atturats

Gall penelitian pengembangan produk operasional yang telah
diartikan sebagai "a process used to dihasilkan; (9) perbaikan akhir develop and validate educational products". 8 Metode penelitian pengembangan ini dimulai dengan mempelajari penelitian atau penemuan yang akan diteliti, dilanjutkan dengan mengembangkan produk dari hasil penelitian tersebut. Selanjutnya dilakukan pengujian, proses pengujian ini dapat dilaksanakan beberapa kali hingga mendapatkan hasil yang diinginkan. Hasil pengembangan produk tersebutlah yang kita sebut sebagai pengembangan dan pengvalidasian produk. terhadap produk yang telah dikembangkan; dan menyebarluaskan produk yang dikembangkan. ${ }^{9}$ Pada penelitian ini hanya akan dipakai penelitian pengembangan dalam bentuk yang sederhana yang terdiri dari : (1) studi pendahuluan; (2) perumusan dan pengembangan produk; dan validasi dan diseminasi produk. Penelitian dengan bentuk sederhana ini dianggap dapat mewakilkan pengembangan materi ajar menulis puisi melalui media audio-visual di SD/MI.

Dalam metode penelitian pengembangan ada beberapa tahap yang harus dilalui, yaitu: (1) meneliti dan mengumpulkan data; (2) merencanakan tujuan; mengembangkan tahapan pertama dalam produk; (4) uji coba produk tahapan pertama; (5) perbaikan produk tahap awal; (6) uji coba utama; (7) perbaikan produk uji coba utama; (8) uji validasi terhadap

\section{KAJIAN TEORI}

\section{Landasan Media Dalam \\ Pendidikan \\ Media dalam pendidikan} memegang peranan yang sangat penting. Bahkan dalam Islam sendiri media merupakan salah satu alat yang dapat dipakai dalam menu ilmu dan pendidikan. Ini tertera dalam Q.S. AlMaidah ayat 16 yang berbunyi: 


\section{At-Turats}

Jurnal Pemikiran Pendidikan Islam

journal homepage: http://jurnaliainpontianak.or.id/index.php/atturats

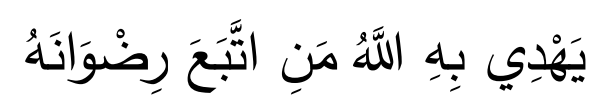

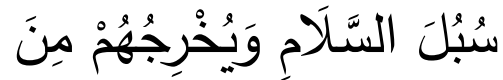

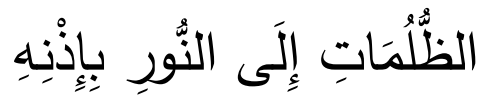

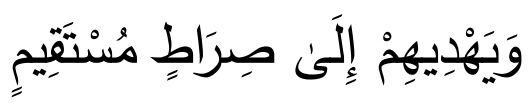

Artinya: "Dengan kitab itulah

Allah menunjuki orang-orang yang mengikuti keridhaan-

Nya ke jalan keselamatan, dan

(dengan kitab itu pula) Allah mengeluarkan orang-orang

itu dari gelap gulita kepada cahaya yang terang benderang dengan seizinNya, dan menunjuki mereka ke jalan yang lurus."

Ayat di atas menunjukkan bahwa Allah sendiri menurunkan AlQur'an dan kitab suci lainnya sebagai media yang membantu menunjukkan jalan yang terang dan penuh keselamatan bagi umatnya. Dari ayat di atas dapat kita ambil kesimpulan bahwa media haruslah mempunyai fungsi dan manfaat sebagai alat membantu seseorang untuk

10 Azhar Arsyad, Media Pembelajaran, (Jakarta: Rajagrafindo Persada, 2011), hlm.9. memahami suatu ilmu pengetahuan. Telah dibuktikan bahwa penggunaan media dalam pendidikan mempunyai pengaruh yang lebih baik dari pada yang tidak menggunakan. Sebagai bukti menurut Levie \& Levie stimulus visual membuahkan hasil belajar yang lebih baik untuk tugas-tugas seperti mengingat, mengenali, mengingat kembali dan menghubungkan fakta dan konsep. ${ }^{10}$ Dari situlah dapat kita lihat bahwa media dala pendidikan mengambil banyak peran penting dalam pemahaman ilmu pengetahuan dan pendidikan. 


\section{At-Turats}

Jurnal Pemikiran Pendidikan Islam

journal homepage: http://jurnaliainpontianak.or.id/index.php/atturats

\section{PEMBAHASAN DAN HASIL} dirinci menjadi dua fase, yaitu

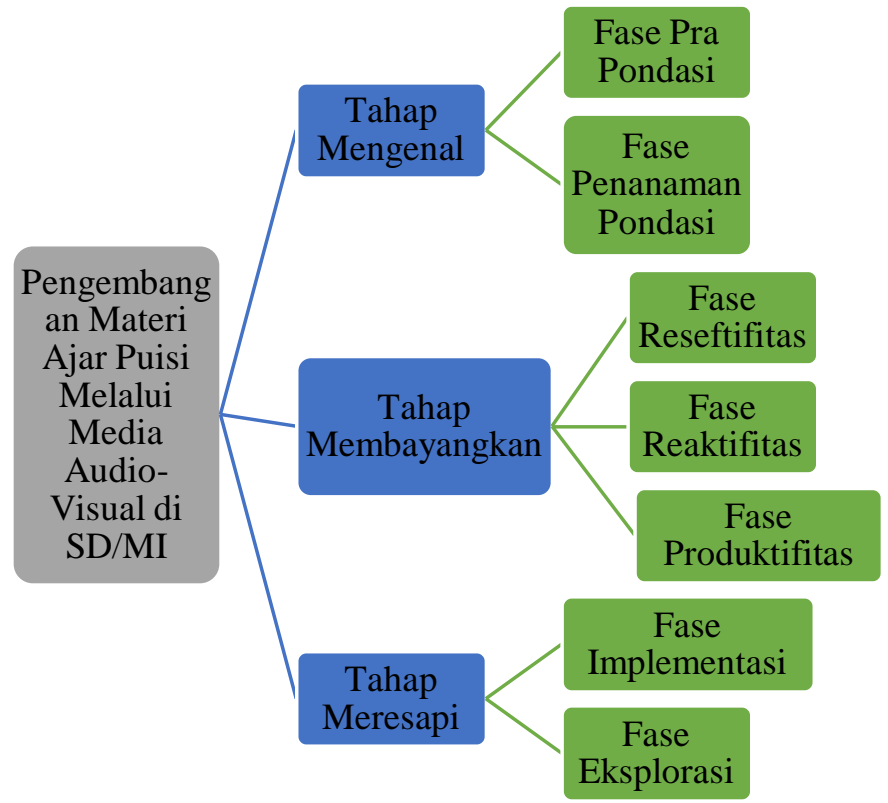

imnlamantaci dan alenlnraci

Bagan Pengembangan Materi Ajar Tahap Menulis Puisi Melalui Media Audio-Visual di SD/MI

Dalam penelitian ini ditemukan tiga tahap pengembangan materi ajar puisi melalui media audiovisual di SD/MI, yaitu: mengenal, membayangkan, dan meresapi. Tahap mengenal dirinci menjadi dua fase, yaitu: pra pondasi dan penanaman pondasi. Dilanjutkan dengan tahap membayangkan yang dirinci menjadi tiga fase, yaitu: reseftivitas, reaktivitas dan produktivitas. Tahap yang terakhir adalah meresapi yang

11 W.J.S. Poerwadarminta, Kamus Umum Bahasa Indonesia, (Jakarta: Balai Pustaka, 2011), hlm.478.

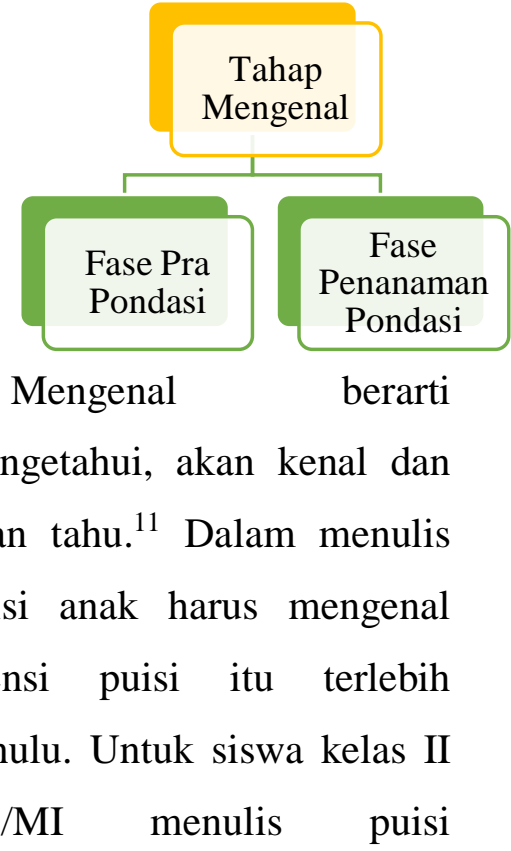

SD/MI menulis puisi 


\section{At-Turats}

Jurnal Pemikiran Pendidikan Islam

journal homepage: http://jurnaliainpontianak.or.id/index.php/atturats

\begin{abstract}
merupakan kegiatan yang
dapat melatih keterampilan

menulis mereka. Tahap

mengenal merupakan tahapan

awal atau pertama dalam

menulis puisi. Pada tahapan

ini anak di perkenalkan

dengan esensi dari puisi dan

seperti apa tema puisi yang

akan ditulis. Pada tahapan

mengenal ini anak akan

dihadapkan pada dua fase

mengenal, yaitu:
\end{abstract}

a. Pra

pondasi

merupakan fase saat

anak diberikan tentang

penjelasn esensi dari

puisi, seperti

pengertian, unsur,

jenis dan langkah-

langkah dalam

menulsi puisi. Pada

fase ini puisi

diperkenalkan kepada

anak kelas II SD/MI

dengan cara yang

sederhana. Untuk

kalimat yang menjelaskan tentang

esensi dari puisi juga

harus dengan kalimat

yang sederhana. Ini

sesuai dengan hasil

wawancara dengan

Ibu

Uswatun

Rochmawati, S.Ag. di

MIN I Bantul

Yogyakarta yang

mengatakan bahwa

anak kelas II belum

dapat mengerti

kalimat yang

kompleks maka harus

dijelaskan dengan cara

yang sederhana dan

mudah dimengerti

oleh mereka sebagai

anak-anak. $^{12}$ Kalimat

penjelasan tentang

menulis puisi haruslah

dibungkus dengan

kalimat yang jelas dan

tidak sulit dipahami

oleh anak usia 6-7

tahun. Kalimat yang

mudah

untuk 


\section{At-Turats}

Jurnal Pemikiran Pendidikan Islam

journal homepage: http://jurnaliainpontianak.or.id/index.php/atturats

dimengerti juga akan

memberikan

gambaran yang mudah

dalam menulis puisi

itu sendiri.

b. Penanaman pondasi

merupakan fase

terakhir dalam tahap

mengenal. Pada fase

ini ini anak

ditanamkan pondasi

dalam menulis puisi

yaitu tema. Tema

dalam menulis puisi

merupakan hal utama

yang harus

diperhatikan. Pada

fase sebelumnya anak-

anak telah mengenal

esensi dari sebuah

puisi maka fase ini

anak di kenalkan

dengan tema puisi

yang akan ditulis.

Mengenalkan tema

puisi pada anak adalah

hal yang sangat

mendasar. Ini sesuai
${ }^{13}$ Hasil Wawancara Guru Kelas II MIN I Bantul Yogyakarta pada Senin tanggal 19 Maret 2018 dengan punuturan dar

Ibu

Uswatun

Rochmawati, S.Ag.

yang menyatakan

bahwa pengenalan

tema puisi yang baik

pada anak sangat

membantu dalam

menulis puisi dengan

baik. $^{13}$

\section{Tahap Membayangkan}

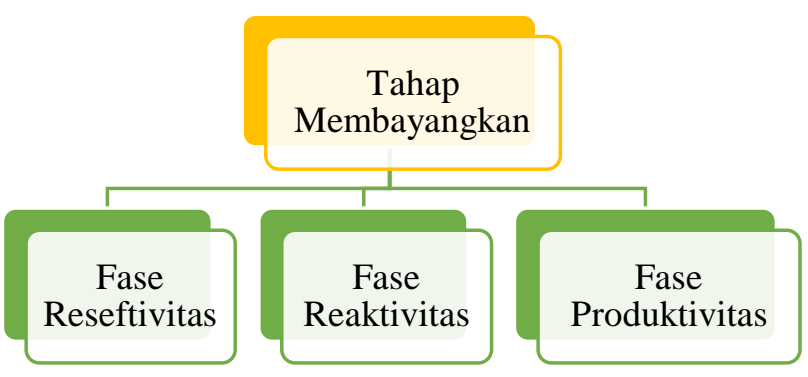

Membayangkan adalah mengadakan bayang-bayang dan menggambarkan. ${ }^{14}$

Tahap membayangkan merupakan tahap saat imajinasi anak dihidupkan dengan cara mereka membayangkan. Ini sesuai yang dinyatakan oleh Ibu Uswatun Rochmawati, S.Ag. bahwa saat usia ini anak

14 W.J.S. Poerwadarminta, Kamus Umum Bahasa Indonesia..., hlm.101. 


\section{At-Turats}

Jurnal Pemikiran Pendidikan Islam

journal homepage: http://jurnaliainpontianak.or.id/index.php/atturats

\begin{tabular}{|c|c|}
\hline $\begin{array}{l}\text { mempunyai imajinasi yang } \\
\text { sangat kuat sehingga akan }\end{array}$ & $\begin{array}{l}\text { Pada tahap membayangkan } \\
\text { ada tiga fase yang haru dilalui, }\end{array}$ \\
\hline lebih mudah untuk & yaitu: \\
\hline membayangkan. ${ }^{15} \quad$ Sesuatu & a. Reseftivitas \\
\hline yang dibayangkan tersebut & merupakan fase disaat \\
\hline merupakan kondisi dari tema & anak mampu untuk \\
\hline puisi yang akan ditulis. Pada & mengenal lingkungan \\
\hline tahap ini visual (gambar) dari & di sekitarnya. Saat \\
\hline tema yang telah diperkenalkan & setelah \\
\hline pada tahap sebelumnya & diperlihatkan \\
\hline diperlihatkan. Anak diminta & mampu \\
\hline untuk memperhatikan gambar & mengidentifikasi \\
\hline dengan seksama dan teliti. & seluruh hal yang ada \\
\hline Saat visual (gambar) telah & visual. \\
\hline diperlihatkan anak akan & Membayangkan akan \\
\hline mampu membayangkan & semakin baik ketika \\
\hline bahkan menempatkan situasi & mengenal \\
\hline sesuai dengan visual tersebut & seluruh aspek yang \\
\hline sehingga tersasa nyata. Sesuai & ada di dalam visual \\
\hline dengan yang diungkapkan & tersebut dengan baik \\
\hline oleh Ibu Uswatun & pula. Kondisi \\
\hline Rochmawati, S.Ag. bahwa & susasana \\
\hline membayangkan adalah cara & diharapkan \\
\hline termudah anak untuk dapat & dalam \\
\hline menulis puisi, karena mereka & membayangkan akan \\
\hline mudah dalam melaksanakan & semakin jelas \\
\hline hal yang & nyat \\
\hline
\end{tabular}

lihat dan rasakan (konkrit). ${ }^{16}$

${ }^{15}$ Hasil Wawancara Guru Kelas II MIN I Bantul Yogyakarta pada Senin tanggal 19 Maret 2018
${ }^{16}$ Hasil Wawancara Guru Kelas II MIN I Bantul Yogyakarta pada Senin tanggal 19 Maret 2018 


\section{At-Turats}

Jurnal Pemikiran Pendidikan Islam

journal homepage: http://jurnaliainpontianak.or.id/index.php/atturats

b. Reaktivitas

merupakan fase di

mana anak bereaksi

dengan kondisi atau

suasana yang

dibayangkan dengan

dengan cara bertanya

kepada guru tentang

segala yang ada di

dalam visual yang

telah diperlihatkan.

Usahakan agar visual

yang dipilih

menggambarkan

kondisi sesuai tema

secara keseluruhan.

Kondisi yang sesuai

dengan tema tidak

akan hanya

mengandung satu

aspek saja.

c. Produktivitas

merupakan fase saat anak menuangkan imajinasi mereka ke dalam bentuk sebuah karya sastra berupa puisi anak sederhana.

Pada fase ini anak- anak

mulai

memunculkan ide-ide

yang mereka rangkai

ke dalam sebuah

kalimat indah yang

sederhana.

\section{Tahap Meresapi}

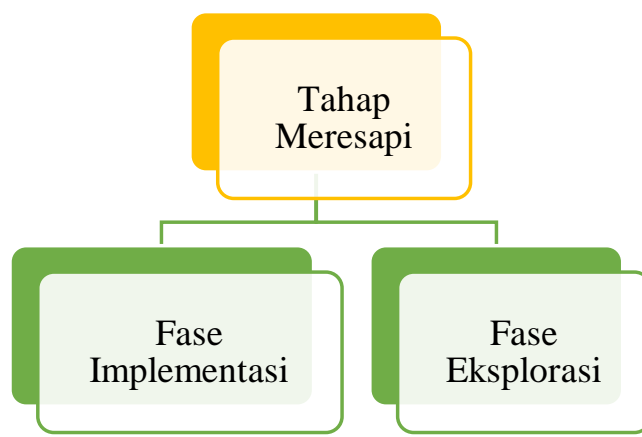

Meresapi

adalah menyerap masuk dalam rongga-rongga, masuk dan melekat. ${ }^{17}$ Tahap ini merupakan tahap pelengkap dari tahap sebelumnya. Setelah melihat visual (gambar) dari tema yang telah ditentukan, maka siswa diminta untuk meresapi atau menyerap dengan mendengarkan audio (suara) yang sesuai tema untuk semakin memperkuat dan

${ }^{17}$ W.J.S. Poerwadarminta, Kamus Umum Bahasa Indonesia..., hlm.821. 


\section{At-Turats}

Jurnal Pemikiran Pendidikan Islam

journal homepage: http://jurnaliainpontianak.or.id/index.php/atturats

melekatkan pembayangan

(imajinasi) yang telah

dibangun pada anak. Audio

(suara) tersebut akan

membuat anak lebih masuk ke

dalam situasi atau kondisi

yang sesuai dengan tema dan

visual sebelumnya. Pada

tahap ini juga melalui

beberapa fase, yaitu:

a. Implementasi

merupakan fase saat

anak mendengarkan

audio yang juga sesuai

dengan tema dan

visual yang telah

diperlihatkan

sebelumnya. Audio

tersebut membuat

anak mudah untuk

menyesuaikan

keadaan diri dalam

bayangannya sesuai

tema dan visual puisi

yang kan ditulis.

Dapat dikatakan fase

ini sebagai fase

adaptasi dengan

tambahan pendukung

yaitu audio. b. Eksplorasi merupakan fase dimana anak mulai menambahkan aspek-aspek yang tidak ada di dalam gambar tapi mereka tuangkan ke dalam tulisan sebagai yang kita sebut citraan dan majas. Fase ini adalah ketika imajinasi anak lebih tajam dan lebih terarah. Lebih tajam dalam membayangkan situasi sesuai tema tanpa perlu lagu memperhatikan aspekaspek di dalam gambar dan tidak keluar dari tema puisi yang ingin di tulis.

\section{SIMPULAN}

1. Media merupakan alat yang dapat membantu berjalannya proses pendidikan. Bahkan media memegang peranan besar dalam menjadi alat pemahaman ilmu pengetahuan dan pendidikan. Allah SWT juga menggunakan 


\section{At-Turats}

Jurnal Pemikiran Pendidikan Islam

journal homepage: http://jurnaliainpontianak.or.id/index.php/atturats

media dalam menyampaikan jalan keselamatan dan pengetahuan bagi hamba-Nya. Media dalam menyampaikan itu semua adalah kitab suci termasuk Al-Qur'an.

2. Tahap menulis puisi melalui media audio-visual yang dapat dilakukan dengan tiga tahapan, yaitu: mengenal, membayangkan, meresapi. Tahap mengenal adalah tahap awal mengenalkan tema puisi yang akan ditulis yang dirinci dalam dua fase, yaitu: fase pra pondasi dan fase penanaman pondasi. Tahap membayangkan adalah tahap anak menghidupkan imajinasi setelah diperlihatkan media visual yang dirinci dalam tiga fase, yaitu: fase reseftivitas, fase reaktivitas dan fase produktivitas. Tahap meresapi adalah tahap dimana kondisi sesuai gambar dan tema didukung dengan audio yang sesuai tema puisi yang dirinci dalam dua fase, yaitu: fase implementasi dan fase eksplorasi.

3. Hasil dari uji coba penelitian ini pada siswa kelas II di MIN I Bantul Yogyakarta menunjukkan bahwa tahap menulis puisi melalui media audio-visual dapat digunakan untuk membantu materi ajar puisi pada kelas rendah. Siswa dapat lebih mudah menulis puisi ketika ditunjukkan visual (gambar) sesuai dengan tema puisi yang ingin ditulis. Audio juga membantu konsentrasi siswa lebih meningkat dan penulisan puisi anak dalam bentuk yang sederhana dapat dilaksanakan sebagaimana mestinya.

\section{DAFTAR PUSTAKA}

Arsyad, Azhar, Media Pembelajaran, Jakarta: Rajagrafindo Persada, 2011.

Borg, Walter R dan Meredith D. Gall, Educational Research An Introduction, Boston: Pearson Education Inc, 2003.

Kustandi, Cecep dan Bambang Sujipto, Media Pembelajaran Manual dan Digital, Bogor: Ghalia Indonesia, 2013. Poerwadinata, W.J.S, Kamus Umum Bahas Indonesia, Jakarta: Balai Pustaka, 2011. 


\section{At-Turats}

Jurnal Pemikiran Pendidikan Islam

Saragih, Maria Sepriyenni, dkk,

"Penggunaan Media Audio

Visual Untuk Meningkatkan

Hasil Belajar Menyimak

Dalam Pembelajaran Bahasa

Indonesia", Jurnal Pendidikan

Untan, 2015.

Sayuti, Suminto A., Berkenalan dengan Puisi, Yogyakarta:

Gama Media, 2008.

Syafi'ie, Retorika Dalam Menulis,

Jakarta: Departemen

Pendidikan dan Kebudayaan, 1988.

Tarigan, H.G., Menulis Sebagai Suatu

Keterampilan Berbahasa,

Bandung: Angkasa, 1994.

Turofingah, Lina, dkk, "Peningkatan

Keterampilan Menulis Puisi

Melalui Penggunaan Media

Audiovisual Pada Siswa

Kelas V SDN Keleng 01", Jurnal Pendidikan FKIP UNS,

Vol. 3 No. 3, 2015.

Waluyo, Herman J., Teori dan

Apresiasi Puisi, Jakarta:

Penerbit Erlangga, 2002. 